\title{
Провідні збудники та стан антибіотикорезистентності у пацієнтів з урологічною патологією
}

\author{
Б. І. Барало, Р. П. Барало, І. В. Барало \\ Вінницький національний медичний університет ім. М. І. Пирогова

\section{Leading causative agents and state of antibioticoresistance in patients, suffering urological pathology}

\author{
B. I. Baralo, R. P. Baralo, I. V. Baralo \\ Vinnytsya National Medical University named after M. I. Pyrogov
}

\section{Реферат}

Мета дослідження. Визначити структуру збудників інфекційних захворювань сечовивідних шляхів (IЗСВШ) та рівень їх резистентності до антибактеріальних (АБ) засобів у пацієнтів з урологічною патологією.

Матеріали і методи. Проаналізовано результати бактеріологічного дослідження 618 зразків сечі дорослих пацієнтів, що звернулись за допомогою в урологічний кабінет поліклініки, та 44 зразків сечі дорослих пацієнтів, яких лікували в урологічному відділенні у 2016 р.

Результати. Встановлена структура збудників ІЗСВШ та рівні їх резистентності до різних груп АБ засобів. Резистентність мікроорганізмів (МО) до АБ засобів у більшості спостережень перевищила 20\%. Згідно з рекомендаціями Європейської асоціації урологів у разі перевищення даного рівня резистентності АБ засоби є неефективними для застосування їх з метою емпіричної антибактеріальної терапії.

Висновок. Зважаючи на високий рівень резистентності МО, що найчастіше спричиняють ІСВШ, емпірична антибактеріальна терапія завжди має супроводжуватись бактеріологічним дослідженням сечі з визначенням чутливості до антибіотиків.

Ключові слова: уропатогенні мікроорганізми; антибіотикорезистентність; полірезистентність.

Abstract

Objective. To determine a structure of the infection causative agents of the urinary ways (ICAUW) and levels of their resistance to antibacterial (AB) medicines in patients, suffering urological pathology, in Vinnytsya Regional Clinical Hospital named after M. I. Pyrogov.

Materials and methods. Results of bacteriological investigations of 618 urea probes in adult patients, who appealed for help in Urological Parlor of Polyclinic Department, and of 44 urea probes in adult patients, who were treated in Urological Department in 2016 yr, were analyzed.

Results. The ICAUW the causative agents structure and levels of their resistance to various AB medicines was established. In majority of the cases the microorganisms resistance to antibacterial preparations have exceeded $20 \%$. In accordance to Guidelines of European Urologists' Association, while this level of resistance is exceeded, AB medicines demonstrate inefficacy while use for empirical antibacterial therapy.

Conclusion. Taking into account a high level of resistance of microorganisms, which cause ICAUW most frequently, the empirical antibacterial therapy always must be accompanied by sowing urine investigation with atibioticogram analysis.

Keywords: uropathogenic microorganisms; antibioticoresistance; polyresistance.

За даними літератури, уропатогенні штами Е.coli спричиняють ІСВШ у 60 - 85\% хворих з урологічною патологією $[1,2]$. Вибирати препарат для емпіричної антибактеріальної терапії необхідно з урахуванням рекомендацій Європейської асоціації урологів, відповідно до яких призначення препарату недоцільно, якщо резистентність штамів МО до нього більше 10 - 20\% [3]. Рівень резистентності провідних збудників гнійно-запальних інфекцій до всіх класів та груп АБ засобів в Україні за 2008 - 2012 pp. такий: S. aureus - 27,3\%, E. faecalis - 35,5\%, E. coli- 28,7\%, Enterobacter - 29,0\%, P. aeruginosa - 49,8\% [4].

Мета дослідження: визначити структуру збудників ІЗСВШ та рівень їх резистентності до АБ засобів у пацієнтів з урологічною патологією.

\section{Матеріали і методи дослідження}

Проаналізовано результати бактеріологічного дослідження 618 зразків сечі дорослих пацієнтів, що звер- нулись за допомогою в урологічний кабінет поліклініки (1-ша група), та 44 зразки сечі дорослих пацієнтів, які знаходились в урологічному відділенні (2-га група) Вінницької обласної клінічної лікарні у 2016 р. Ідентифікація МО проведена за біохімічними та культурально-морфологічними властивостями на класичних диференціально-діагностичних середовищах за стандартними методиками. Чутливість збудників до різних груп АБ засобів вивчали диско-дифузійним методом за Bauer-Kirby $з$ використанням комерційних дисків (HI MEDIA, Індія) на середовищах Мюллера-Хінтона виробництва Україна в бактеріологічному відділенні клінікодіагностичної лабораторії лікарні. Оцінювали граничні значення діаметрів (мм) зон пригнічення росту згідно з критеріями визначення чутливості МО, наведеними в Наказі МО3 України від 05.04.2007 № 167 «Про затвердження методичних вказівок "Визначення чутливості мікроорганізмів до антибактеріальних препаратів", 
розробленого з метою реалізації основних положень Глобальної стратегії ВООЗ зі стримування стійкості до антимікробних препаратів [5]. Загалом визначали чутливість: Enterobacteriaceae (E. coli, E. faecalis, E. faecium, K. pneumonia) - до ампіцилін/сульбактаму, амоксицилін/клавуланату, цефуроксиму, цефоперазону, цефотаксиму, цефепіму, гентаміцину, амікацину, налідіксової кислоти, норфлоксацину, ципрофлоксацину, левофлоксацину, гатіфлоксацину, хлорамфеніколу, ко-тримоксазолу;

Enterococcus spp. - до ампіцилін/сульбактаму, еритроміцину, ванкоміцину, лінезоліду, хлорамфеніколу, доксицикліну, ципрофлоксацину, норфлоксацину, левофлоксацину, гатіфлоксацину;

P. aeruginosa - до гентаміцину, амікацину, тобраміцину, ципрофлоксацину, левофлоксацину, цефтазидиму, цефоперазону, цефепіму, іміпенему, меропенему;

Staphylococcus spp. - до ампіцилін/сульбактаму, еритроміцину, хлорамфеніколу, доксицикліну, ципрофлоксацину, норфлоксацину, левофлоксацину, гатіфлоксацину, ко-тримоксазолу, гентаміцину, амікацину.

Штами МО відносили до чутливих, помірно стійких або стійких (резистентних) до певного АБ засобу в залежності від діаметру зони пригнічення росту. Статистична обробка результатів здійснена за допомогою пакета прикладних програм Statistica 8.0 (StatSoft, США). Показники вважалися вірогідними при значеннях $\mathrm{p}<0,05$.

\section{Результати}

У 24 (54,55\%) пацієнтів 2-ої групи виявлені уропатогенні МО в концентрації менше $10^{3}$ КУО/мл. Серед збудників IЗСВШ домінували E. coli (33,3\%) та E. faecalis (25\%), частка E. faecium та P. aeruginosa була однаковою - по $8,3 \%$, як і частка коагулазонегативних стафілококів (S. epidermidis, S. haemoliticus) - відповідно по 4,2\%.

У пацієнтів 1-ої групи уропатогенні МО в концентрації більше $10^{3}$ КУО/мл виявлені у 295 (47,7\%) посівах сечі. У структурі уропатогенних МО грамнегативні переважали над грампозитивними - відповідно у 194 (65,4\%) і 101 (34,2\%) посіві сечі. Серед збудників ІЗСВШ домінували Е. coli та E. faecalis - відповідно у 134 (45,4\%) та 56 (19,0\%) посівах. Рідше зустрічали коагулазонегативні стафілококи (S. epidermidis, S. haemolyticus) - відповідно у 6,1\% та 3,72\% посівів, K. pneumonia - у 5,42\%, P. aeruginosa - y 4,1\% посівів.

На основі критеріїв інтерпретації результатів визначення чутливості МО до антибіотиків згідно з граничними значеннями діаметрів зон пригнічення росту Е. coli у хворих 2-ої групи виявили стійкою до пеніцилінів у 35,0\%, цефалоспоринів - у 30,0\%, фторхінолонів - у $38,2 \%$, ко-тримоксазолу - у 25,0\% посівів. У пацієнтів $1-$ ої групи даний показник був більш стійким: до пеніцилінів - 49,0\%, ко-тримоксазолу - 38,0\% та мав високу резистентність до фторхінолонів - 32,4\%.

Серед грамнегативних МО у пацієнтів 1-ої групи резистентність E. coli, K. Pneumonia перевищувала гранично допустимі рівні (10 - 20\%) щодо пеніцилінів, цефалоспоринів, хінолонів, аміноглікозидів, левоміцетину та ко-тримоксазолу, що утруднює емпіричний вибір цих груп антибіотиків у пацієнтів з урологічною патологі- єю. Р. aeruginosa мала високий рівень стійкості, окрім перелічених антибіотиків, до аміноглікозидів і карбапенемів - відповідно 52,4\% і 27,3\%. P. aeruginosa є одним із домінуючих збудників інфекцій в урологічних стаціонарах у світі. Маючи лише два результати виділення даного збудника, ми не можемо стверджувати про репрезентативність даних, хоча отримані результати посівів на чутливість підтверджують потребу пильної уваги до даного патогенного MO. Резистентність Р. aeruginosa до цефалоспоринів виявлена у 66,6\%, карбапенемів - у 50,0\%, до аміноглікозидів - у 33,3\%, фторхінолонів - у 100\% посівів.

Резистентність ентерококів до антибіотиків у пацієнтів 2-ої групи теж виявилась високою. Е. faecalis був стійким до макролідів (33,3\%), фторхінолонів (38,8\%), гентаміцину (50\%), хлорамфеніколу (16,6\%).

У пацієнтів урологічного кабінету серед грампозитивних MO S. Epidermidis виявився чутливим до аміноглікозидів, доксицикліну та стійким до еритроміцину (33,4\%), фторхінолонів (13,0\%), хлорамфеніколу (16,7\%), ко-тримоксазолу $(23,53 \%)$. Щодо E. faecalis резистентність менше 10\% зафіксована до ванкоміцину $(2,2 \%)$ та лінезоліду (4,9\%). Стійким даний МО був до еритроміцину (50,9\%), фторхінолонів (29,44\%), хлорамфеніколу (28,6\%), доксицикліну (29,6\%), гентаміцину (22,2\%).

Резистентність до трьох і більше антибіотиків розцінювали як полірезистентність. Е. coli, яку виявляли найбільш часто, була полірезистентною у 4 (50,0\%) у хворих 2-ої групи і 47 (35,1\%) пацієнтів 1-ої групи.

Полірезистентна Е. coli мала високий рівень резистентності до захищених пеніцилінів, цефалоспоринів, фторхінолонів і у хворих 1-ої групи, і уу хворих 2-ої групи - відповідно 20,7; 31,0; 41,4 і 28,4; 19,3; 34,5. У пацієнтів 1-ої групи полірезистентна E. coli була високорезистентною ще й до ко-тримоксазолу (12,9\%).

Полірезистентна E. coli виявилась нечутливою до таких антибіотиків: цефуроксим, цефотаксим, ампіцилін/ сульбактам, амоксицилін/клавуланат, норфлоксацин, ципрофлоксацин, левофлоксацин, гатіфлоксацин, котримоксазол в обох групах пацієнтів; чутливість полірезистентної Е. coli зберігалась в обох групах пацієнтів до цефоперазону, гентаміцину та амікацину.

Згідно з критеріями виявлення штамів E. coli, що можливо продукують бета-лактамазу розширеного спектру дії, проаналізовано граничні значення зон пригнічення росту цього МО цефотаксимом. Результат виявився позитивним (діаметри зон пригнічення росту менше 27 мм) у 62,5\% пацієнтів 2-ої групи та у 43,8\% пацієнтів 1ої групи. Досліджували полірезистентну E. coli та E. coli, помірно стійку до цефалоспоринів другого та третього поколінь.

\section{Обговорення}

У пацієнтів з урологічною патологією, що перебували у стаціонарі переважали збудники урологічних інфекцій, які є представники родини Enterobacteriaceae - Е. coli, E. faecalis. Дані MO виявляли як у пацієнтів 2-ої групи (58,3\%), так і у хворих 1 -ої групи (64,4\%). Значно рідше висівались коагулазонегативні стафілококи - Е. faecium, P. aeruginosa, K. Pneumonia. Рівні резистентності грамнегативних MO (E. coli, P.aeruginosa, K. Pneumonia) 
до антибіотиків з груп пеніцилінів, цефалоспоринів, хінолонів, ко-тримоксазолу, що найчастіше застосовуються, перевищують у пацієнтів з урологічною патологією Вінницької області 10 - 20\%. Це ставить під сумнів емпіричний вибір даних антибіотиків і свідчить про необхідність проведення всім пацієнтам бактеріологічного дослідження сечі для виявлення мікрофлори і ії чутливості до антибіотиків. E. faecalis як другий за значимістю патогенний МО, що спричиняє урологічні інфекції, показав високий рівень резистентності (більше 10 - 20\%) до антибіотиків з груп макролідів, хінолонів, аміноглікозидів, хлорамфеніколу. Це також підтверджує необхідність дослідження мікрофлори і їі чутливості до антибіотиків. E. coli як домінуючий збудник IЗСВШ у пацієнтів 3 урологічною патологією у Вінницькій області виявилась полірезистентною у 50,0\% посівів сечі пацієнтів 2ої групи і 35,1\% посівів сечі пацієнтів 1-ої групи. Також Е. coli є збудником, небезпечним у плані продукування бета-лактамази розширеного спектру дії. Таким чином, Е. coli $€$ небезпечним збудником із важко прогнозованою ефективністю емпіричної антибактеріальної терапії.

\section{Висновки}

1. Враховуючи ріст антибіотикорезистентності МО, всім пацієнтам з ІЗСВШ перед призначенням АБ засобів необхідно проводити бактеріологічне дослідження сечі для виявлення мікрофлори і ії чутливості до антибіотиків.

2. У разі виявлення МО, резистентних до призначеного АБ засобу, необхідна його відміна і призначення препарату, до якого чутлива мікрофлора.
3. Оцінку концентрації МО в сечі слід вважати одним із критеріїв тривалості антибіотикотерапії.

4. Для зниження рівня антибіотикорезистентності MO необхідні заходи на системному рівні, такі як заборона безрецептурного відпуску АБ засобів, впровадження протоколів із зазначенням критеріїв тривалості антибіотикотерапії та ії відміни, скорочення тривалості лікування в стаціонарі, видалення катетерів у якнайкоротші терміни.

\section{References}

1. Guevara N, Guzmán M, Merentes A, Rizzi A, Papaptzikos J, Rivero N, et al. Antimicrobial susceptibility patterns of Gram-negative bacteria isolated in urinary tract infections in Venezuela: Results of the SMART study 2009-2012. Rev Chilena Infectol. 2015 Dec;32(6):639-48. doi: 10.4067/S0716-10182015000700005.

2. Miranda EJ, Oliveira GS, Roque FL, Santos SR, Olmos RD, Lotufo PA. Susceptibility to antibiotics in urinary tract infections in a secondary care setting from 2005-2006 and 2010-2011, in São Paulo, Brazil: data from 11,943 urine cultures. Rev Inst Med Trop Sao Paulo. 2014 JulAug;56(4):313-24. doi: 10.1590/S0036-46652014000400009.

3. Glybochko VP, Aljaev JuG, editors. Integrativnaja urologija. Moskva: Medforum; 2014. 432p. [In Russian].

4. Ministerstvo okhorony zdorovia Ukrainy. Materialy naukovo-praktychnoi konferentsii z mizhnarodnoiu uchastiu "Aktualni problemy antybiotykorezystentosti, dezinfektsii ta sterylizatsii". Kyiv: NTMT; 2013. 173 p. [In Ukrainian]. 